\title{
Koninkryksteologie of verbondsteologie?
}

\author{
Adrio Kōnig
}

\begin{abstract}
Kingdom Theology and Covenant Theology

One of the tasks of Systematic Theology is to relate different aspects of the Christian Faith. This is often done by using a key concept. Well-known in Reformed Theology are the concepts Kingdom of God and Covenant. To put a theology developed along one key concept over against other theologies, is a rather apologetic and unfruitful approach. To relate such theologies meaningfully to each other, is an ecumenical, daring and rewarding approach. Both a Kingdom Theology and a Covenant Theology can be enriched by such an exercise. A Kingdom Theology tends to become impersonal and hard, while a Covenant approach may foster familiarity. Mutual exposure may prevent such extremes.
\end{abstract}

\section{DIE ROL VAN KERNBEGRIPPE}

Een van die belangrikste take van die dogmatiek (sistematiese teologie) is om samehangend oor die openbaring en die geloof na te dink. Daar is die boodskap oor God, oor Christus, en oor die Heilige Gees, daar is die boodskap oor die skepping, oor Israel, oor die kerk en die heil, en in die heil is daar die regverdiging, die heiliging, die volharding en nog baie meer fasette. Oor al hierdie fasette moet daar in die kerk gepreek word. In die preek moet fasette van die Bybelse boodskap met ons huidige werklikheid en lewe in verband gebring word.

Maar die gevaar bestaan altyd dat ons nie samehangend preek nie, dat die eenheid in ons prediking ontbreek, en dat die gemeente se geloof dan ook nie meer 'n sinvolle geheel vorm en hulle nie 'n samehangende greep op die werklikheid kry nie. In die sistematiese teologie probeer ons dan die kerk help om die verskillende fasette van die geloof sinvol met mekaar in verband te bring.

Hiervoor word dikwels gebruik gemaak van kernbegrippe om die verskillende fasette van die openbaring met mekaar in verband te probeer bring. In ' $n$ beperkte sin kry ons talle voorbeelde daarvan. Regverdiging en heiliging word met mekaar in verband gebring as 
indikatief en imperatief. Die werk van Christus en die werk van die Gees word met mekaar in verband gebring as objektief en subjektief, of as verwerwing van die heil en toepassing van die heil. (Die vraag is nie nou of dit goeie tiperinge is nie.)

Daar is ook begrippe wat ' $n$ meer omvattende diens lewer. In die Lutherse teologie word wet en evangelie gebruik om talle fasette van die Bybelse boodskap met mekaar in verband te bring. In die Gereformeerde tradisie word sonde en genade gebruik. Selfs hierdie begrippe is egter nie heeltemal ruim genoeg nie. Daarom het die Lutherse teologie naas wet en evangelie ook ander begrippe nodig soos die verborge God en die geopenbaarde God, en in die Gereformeerde teologie word skepping, sondeval en verlossing as ' $n$ uitbreiding van sonde en genade gebruik.

Daar het egter in die geskiedenis van die teologie min begrippe na vore gekom wat kon dien as 'n sleutel om die hele Christelike geloof samehangend te probeer interpreteer. Tog is daar in die Gereformeerde teologie minstens twee wat hiervoor in aanmerking kom: die koninkryk van God en die verbond. Dit sou ' $\mathrm{n}$ baie interessante historiese studie wees om na te gaan hoe hierdie twee begrippe as sleutels gefunksioneer het, en hoe hulle onderskeidelik ons insig in die evangelie beïnloed het.

Voordat' $n$ kort vergelyking in die res van hierdie bydrae getref word tussen teologieë wat rondom dié twee kernbegrippe gevorm kan word, nog een opmerking.

Dit is jammer dat daar dikwels in die teologie 'n vorm van eksklusiwisme heers waarin daar by voorkeur in negatiewe terme gedink word. As iemand kies vir wet en evangelie as kernbegrip, dan word sonde en genade negatief beoordeel - of andersom. Daarmee verloor ons uit die oog dat die keuse van so 'n kernbegrip nie so 'n maklike saak is nie. Daar is ' $n$ ryk verskeidenheid fasette in die Bybel. Dit is trouens hoogs onwaarskynlik dat ons een enkele begrip sal kry wat alle fasette ongedwonge en sinvol met mekaar in verband sal bring. Daarom sou dit veel verrykender wees as ons liewer probeer om die waarde en bydrae te bepaal wat elkeen van hierdie begrippe kan lewer.

Dit sou veel meer spreek van 'n gees van ekumeniese benadering, van onderlinge vertroue en waardering, van nederige erkenning dat teologie mensewerk is met al die gewone beperkings en tekortkomings wat aan mensewerk verbonde is. 


\section{2. 'N OORSIGTELIKE VERGELYKING VAN KONINKRYKSTEOLOGIE EN VERBONDSTEOLOGIE}

In hierdie gees gaan nou 'n vergelyking getref word tussen die samehangende betekenis wat elk van hierdie twee kernbegrippe vir ons insig in die evangelie kan hê. Die punt sal gemaak word dat elke begrip 'n sinvolle en belangrike bydrae kan lewer omdat elkeen 'n eie beklemtoning in die Christelike geloof indra, 'n bydrae wat nodig is, selfs onontbeerlik, en wat nie so maklik deur die ander begrip gelewer kan word nie. Uiteraard is dit ' $n$ vergelyking tussen twee idealtipes wat nie aan bepaalde teoloë se werk gekoppel is nie. Maar dit sou nie onmoontlik wees om hier en daar die teologie van JA Heyns in die koninkryksteologie te herken nie, en die van $\mathrm{H}$ Berkhof in die verbondsteologie.

'n Teologie van die koninkryk van God sal veral die heerskappy van God, sy soewereiniteit, vrymag en almag beklemtoon, en daarmee saam die onmag en afhanklikheid van die mens. Die neiging sal dus wees om die afstand tussen God en mens en die grootheid van God teenoor die kleinheid van die mens te beklemtoon.

Daarteenoor sal 'n verbondsteologie daartoe neig om die liefde van God, sy goedheid en genade te beklemtoon, en daarmee saam die nabyheid van God en die verbondenheid van God en mens.

Weens die nadruk op die grootheid van God en die afstand tussen God en mens, sal 'n teologie van die koninkryk waarskynlik meer vanuit die ewigheid werk. Dit sal die Ewige Raad, voorbeskikking en uitverkiesing van God beklemtoon, en neig om 'n sterker spanning tussen ewigheid en tyd te aanvaar, met die tyd en die geskiedenis hoofsaaklik as die ruimte waar God se ewige Raadsbesluite uitgevoer word, en met relatief min nadruk op die beslissende waarde van die geskiedenis en die konstitutiewe rol van die mens.

Daarteenoor sal 'n verbondsteologie wat meer nadruk lê op die verbondenheid van God en mens, sterker histories werk, die unieke betekenis van die geskiedenis meer beklemtoon. Dit sal veral nadruk lê op God én mens se werklike betrokkenheid by die geskiedenis as egte verbondsgebeure wat van twee kante bepaal word. Hier sal meer ruimte wees vir die 'weerloosheid' van God (Berkhof) en die nuwe inisiatiewe van God, sy reaksies op werklik nuwe situasies in die geskiedenis.

Dit is egter nie noodwendig waar dat 'n teologie van die koninkryk minder ruimte vir die mens sal hê as 'n verbondsteologie nie. Maar na 
alle waarskynlikheid sal dit 'n ander plek aan die mens toewys. Die wet sal beklemtoon word as die wyse waarop God sy gesag oor sy skepping uitvoer, terwyl die mens dan bo alles gehoorsaam aan God se wet moet wees. Die eer van God (soli deo gloria) sal bo alle dinge beklemtoon word, en die mens sal volkome hieraan diensbaar wees. Dit is nie onmoontlik dat daar in bepaalde uiterste vorme van hierdie teologie aanvaar kan word dat selfs die ewige verwerping en die ewige verdoemenis van mense tot die 'eer van God' bydra nie (Boettner).

Daarteenoor sal die verbondsteologie waarskynlik neig om ' $n$ ruimer rol aan die mens toe te ken, en te beklemtoon dat die mens ' $n$ wesenlike aandeel het in die vorming van die geskiedenis. Omdat God se liefde hier sterker beklemtoon word, sal daar moontlik mensliker en 'sagter' oor die mens gedink word en meer probleme ondervind word met die ewige verderf (Berkhof). Andersyds is dit moontlik dat die verbondsteologie meer nadruk op die onderlinge verbondenheid van mense, en op medemenslikheid as die vorm van menswees sal lê, al is dit nie noodwendig dat die koninkryksteologie minder oog hiervoor sal hê nie.

In die werk van Christus mag die koninkryksteologie meer nadruk lê op die Godheid van Christus en op dit wat Christus vir ons gedoen het, buite ons en sonder ons, terwyl die verbondsteologie moontlik eerder die mensheid van Christus sal beklemtoon en dit wat Christus in ons doen en waaraan ons saam met Christus deel het. In hierdie kontras word die neiging tot afstand in die koninkryksteologie, en die neiging tot verbondenheid in die verbondsteologie konsekwent voortgesit. Dit beteken dat die koningkryksteologie meer nadruk sal lê op die vergifnis van sonde, en die verbondsteologie op die nuwe lewe.

Die koninkryksteologie sal waarskynlik meer nadruk lê op die regverdiging, en die verbondsteologie op die heiliging. Die koninkryksteologie mag neig om 'n negatiewe blik op die mens te hê en groter nadruk te lê op die totale verdorwenheid van die mens, die feit dat die mens net uit genade en net deur Christus gered word, en op die 'gemengde' karakter van die Christen se lewe (tegelyk regverdig en sondaar). Daarteenoor mag die verbondsteologie meer nadruk lê op ons nuwe lewe, op 'n gesonde vorm van 'synergisme' (menslike 'samewerking' met God) in die heiliging, op ons oorwinning oor die sonde (hopelik as ons deelname aan Christus se opstandingslewe en nie as ons teenprestasie op die genade nie).

Die koninkryksteologie sal meer nadruk lê op Christus se hemelvaart, op sy wêreldwye heerskappy 'oor elke duimbreedte van die skepping' en op die kerstening van die totale samelewing in al sy verbande om tot 
gehoorsaamheid aan Christus te kom. Hiermee saam gaan gewoonlik besondere nadruk op die kultuurtaak van Christene om 'n Christelike samelewing te skep. Hierdie eie christelike kultuur is soms baie sterk antiteties teenoor die res van die 'samelewing' gesien, alhoewel kompromie en samewerking op sekere opportunistiese punte nie noodwendig uitgesluit is nie (Kuyper).

Teenoor hierdie nadruk op die heerskappy en oorwinning van Christus as verlengstuk van die almag en heerskappy van God in die koninkryksteologie, sal die verbondsteologie meer nadruk lê op die werk van die Heilige Gees, op die 'weerloosheid' van God in die Gees, op die vrug van die Gees as liefde, vriendelikheid, vrede, ensovoorts, waardeur mense eerder jaloers gemaak as oorwin word, waardeur die wêreld in die kerk 'n lokkende voorbeeld kry van wat God ook met hulle wil doen. Dit kan in die verbondsteologie dus meer om oorreding as oorwinning gaan.

In die koninkryksteologie kan meer nadruk gelê word op Christus se hoofskap en heerskappy in die kerk, op die kerk as 'n regsinstituut met ' $n$ kerkorde, en op die ampsdraers as die mense wat deur Christus gekies is om namens Hom die kerk te regeer. Hier kan dus ook meer nadruk op die gesag van die breër ('hoër'!) kerklike vergaderings val (ring en sinode).

Daarteenoor kan die verbondsteologie meer nadruk lê op die kerk as liefdesgemeenskap en as liggaam van Christus waarin elke lidmaat 'n besondere gawe ontvang het om in diens van almal te beoefen, en waarin die besondere ampte ' $n$ veel kleiner rol speel en eerder die lewe van die gemeente krities begelei as beheer.

Die koninkryksteologie sal neig in die rigting van formeler, sterker gereglementeerde eredienste waar die rol van die predikant oorheers, terwyl die verbondsteologie mag neig na 'n meer informele gemeentebyeenkoms waar die spontaner bydraes van enige van die lidmate 'n groter rol speel.

\section{VERANTWOORDENDE OPMERKINGS}

Die eerste belangrike opmerking is dat tot dusver so min moontlik van evaluering gebruik gemaak is, juis in 'n poging om eerder beskrywend te wees. Dit is tog opsigtelik dat in die meeste gevalle die kontraste tussen die twee tipes teologie eerder onderling aanvullend en verrykend is as noodwendig eksklusief. Sowel God se heerskappy as sy 
liefde is belangrik, en sowel Christus se werk vir ons as sy werk in ons. En sowel 'n erediens wat meer formeel en amptelik verloop, as ' $n$ meer informele gemeentebyeenkoms het waarde. Dit is dus in die meeste gevalle waarskynlik nie nodig om kant te kies nie.

Trouens al sou 'n mens die een tipe teologie bo die ander verkies, waarmee as sodanig geen fout gevind kan word nie, behoort ' $n$ mens doelbewus ook voortdurend iets van die ander benadering te onthou en te realiseer. Immers die koninkryksteologie kan maklik formeel en hard en styf word as God eensydig as die Almagtige Heerser gesien word, as Christus se waarde tweeduisend jaar gelede vir ons aan die kruis eensydig beklemtoon word, as die gemeente gesien word as 'n formeel gestruktureerde groep, en die 'erediens' as ' $n$ formeel bemiddelde byeenkoms. Juis dan het die verbondsbenadering besondere waarde om die liefde en nabyheid van God te beklemtoon, die nuwe lewe waaraan Christus ons nou deel gee, die gemeente as liefdesgemeenskap, en die gemeentebyeenkoms as spontane gemeenskap met God en onderlinge diens aan mekaar. Die verbondsteologie maak 'n stywe, formele, koue benadering sagter, warmer en mensliker.

Maar aan die ander kant kan 'n verbondsbenadering lei tot ' $n$ eensydige beklemtoning van die liefde van God ten koste van sy heiligheid. Dit kan lei tot gemeensaamheid in plaas van gemeenskap met Hom, tot ' $n$ gebrek aan eerbied en die nodige afstand wat daar inderdaad tussen God en mens moet wees, tot 'n gemeentebyeenkoms waarin alles beperk bly tot wat ons vir mekaar kan gee, en waar daar nie meer regtig iets teregkom van die amptelike verkondiging van die evangelie wat krities teen ons idees en voorliefdes ingaan en ons teregwys en verryk nie. Dan is die nadruk op 'n meer formele, gestruktureerde byeenkoms onontbeerlik. Dan moet ons weer opgeroep word om die grootheid en heiligheid van God te oordink, om nederig en gehoorsaam voor sy wet te buig, en om dankbaar sy vrye en onverdiende genade in Christus te omhels.

Dit is in die tweede plek besonder interessant hoeveel ruimte beide die koninkryksteologie en die verbondsteologie vir 'n bevrydingsteologie bied. Die koninkryksteologie se nadruk op Christus se hemelvaart en heerskappy oor 'elke duimbreed van die samelewing', en die nadruk op 'n Christelike kultuur wat daaruit voortvloei, bied al die ruimte vir 'n goed ontwikkelde bevrydingsteologie. As ons ook in ons politiek Christene moet wees, kan ons nie dáár anders optree as in reg en geregtigheid, in regverdigheid en dus met gelyke regte en geleenthede vir alle mense nie. In die Naam van God die Almagtige roep Amos die 
volk op tot verantwoording oor hulle sosiale onreg teenoor die armes en regteloses. Daarom behoort elke vorm van koninkryksteologie die owerheid op te roep tot verantwoording oor die onreg en diskriminasie teenoor gekleurdes in ons land.

Ook die verbondsteologie bied besondere ruimte vir die bevrydingsteologie. As God liefde is, as God in sy liefde naby ons kom en veral optree as die God van die regteloses en verdruktes in Israel, en as die kerk die liefdesgemeenskap van gelowiges is wat mekaar dien deur die gawes van die Gees, dan is dit vanselfsprekend dat gelowiges 'n besondere oog, hart en hand sal hê vir regtelose en verdrukte mense, hulle sover moontlik sal help en bystaan, en aan die owerheid en ander sektore van die samelewing sal toon hoe mense vir mekaar omgee en ander se belange hoër ag as hul eie.

In die derde plek is dit nodig om baie deeglik te onderskei tussen verskillende vorme van koninkryksteologie en verbondsteologie. Die argument tot dusver kan die wanindruk skep dat daar net een koninkryksteologie en net een verbondsteologie is. Dit is ver van die waarheid. Eintlik sou 'n mens vooraf die begrippe deeglik moes omskryf sodat dit van die begin af duidelik kan wees wat jy onder koninkryk van God of verbond verstaan. Daar is byvoorbeeld in die Dispensasionalisme ' $n$ baie interessante vorm van koninkryksteologie wat ooglopend van die Gereformeerde model verskil, en daar is selfs onder die Jehova-Getuies een wat nog veel meer afwykend is. En daar is ook verskillende voorbeelde van verbondsteologie. Die Amerikaanse Covenant Theology en die 'Potchefstroomse' verbondsteologie verskil baie van Berkhof s'n. Eersgenoemde twee is baie meer strak, eksklusief, onhistories en formeel as díe van Berkhof en sluit trouens baie makliker by 'n selfs redelik erg geformaliseerde koninkryksteologie aan.

Vierdens moet ons onthou dat ons natuurlik nooit 'n 'suiwer' koninkryks- of verbondsteologie kry nie, dit wil sê 'n teologie wat net deur hierdie een begrip bepaal word nie. Elke teoloog het ook ander sake wat die vorm van sy of haar teologie medebepaal. Barth het byvoorbeeld een van die konsekwentste vorme van verbondsteologie, maar sy teologie vertoon tog op sekere punte 'n gebrek aan historiese bewussyn. Sy geweldige nadruk op die oormag van God en die oormag van sy ewige genadebeslissing bring mee dat hy nouliks die werklikheid van die stryd en die oorwinning van Christus in die geskiedenis tot sy reg kan laat kom. Alles is al 'zum vornherein' beslis. Eintlik word die oormag van God se ja net geopenbaar in die geskiedenis. Daar is nie 'n werklike oorgang van sy toorn na sy genade nie omdat sy ja vooraf 
vasstaan. Daar kan dus niks beslissends in die geskiedenis plaasvind nie. Sy toorn is eintlik net ' $n$ vorm van sy ewige genade.

Hierdie gebrek aan historiese bewussyn is nie net moontlik in ' $n$ konsekwente verbondsteologie nie. Trouens ' $n$ bepaalde punt in die koninkryksteologie van JA Heyns vertoon 'n opvallende ooreenkoms hiermee. Volgens Heyns kom die koninkryk van God oppermagtig en onstuitbaar in die geskiedenis, só dat niks en niemand dit werklik kan teenstaan nie, dat dit op geen wyse in sy triomfantelike tog gesluit of van koers af gebring kan word nie, ja, dat God selfs alle weerstand in diens neem in die koms van die koninkryk.

Maar ook oor hierdie perspektief van Heyns sou gevra kon word of dit noodwendig is in ' $n$ koninkryksteologie. Veral as ' $n$ mens die historiese karakter van die koms van die koninkryk volgens die Sinoptiese Evangelies in ag neem, die werklike beslissings wat in Jesus se aardse optrede val, kan 'n koninkryksteologie óók voluit erns maak met die geskiedenis, sodat die koms van die koninkryk 'n werklike historiese gebeure is, en nie bloot die openbaring van die oppermag en vooraf oorwinning van God nie.

'Afwykende' vorme van ideaaltipes van teologie, dit wil sê vorme wat op bepaalde punte van 'n ideaaltipe verskil, kan die ideaaltipe óf problematiseer óf verryk. Dit bly 'n uiters subjektiewe beslissing of so ' $n$ alternatief negatief of positief beoordeel moet word. Persoonlik beoordeel ek bogenoemde gebrek aan historiese bewussyn by Barth en Heyns negatief. Maar 'n ander teoloog mag dit juis positief beoordeel veral een wat self meen dat die geskiedenis eerder openbaringsruimte as beslissingsruimte is.

\section{4. 'N ESKATOLOGIESE VERBONDSTEOLOGIE}

Persoonlik verkies ek 'n eskatologiese verbondsteologie as ' $n$ alternatiewe vorm van verbondsteologie. Die begrip 'eskatologies' is nie bloot 'n toevoeging nie, maar eerder ' $n$ karakterisering van die verbondsbeskouing. Wanneer eskatologie in die betekenis van doel gebruik word, en die verbond as God se skeppingsdoel beskou word (Barth), word daar ' $n$ besondere beweging en toekomsgerigtheid in die verbondsteologie ingebou, juis omdat God se skeppingsdoel nie by die skepping gerealiseer is nie, maar om verskillende redes van die begin af in die toekoms verwag word. Op sigself sou dit net hoef te beteken dat die doel iewers in die toekoms gerealiseer sal word, wat niks meer vereis as 
'n redelike 'plat', liniêre geskiedenisvisie nie. Dit blyk egter reeds vroeg in Israel se ervaringe met God dat God se doel met hulle nie so enkelvoudig is nie. Hy gee telkens nuwe beloftes wat Israel elke keer weer op die toekoms rig, sy beloftes word altyd ryker sodat hulle verwagting ook groter word, die vervulling van die beloftes is ryker as die beloftes self, en nogtans ontwikkel die beloftes in die vervulling ' $n$ meerwaarde wat hulle hul beloftekarakter laat behou en die gelowiges na 'n verdere vervulling laat uitsien (Moltmann). Die dade van God in die geskiedenis op pad na die realisering van sy skeppingsdoel, word 'n merkwaardige verrykende en oortreffende herhaling van sy skeppingswerk. Dit word weerspieël in die titel van my skeppingsleer: Hy kan weer en meer (1982).

Hierdie eskatologiese verbondsbenadering moet egter nie verwar word met ' $n$ 'ewigheidsbenadering' waarvolgens God 'n uitgewerkte plan het wat net in die tyd gerealiseer word nie (Boettner), want die herhalende en verrykende vervulling ontbreek in hierdie 'ewige raadsplan'-benadering, waarin die beslissende waarde van die geskiedenis dan ook verlore gaan.

Die feit dat dit 'n eskatologiese verbondsteologie is, skep ruimte vir die werklike rol van die mens, naas God, in die realisering van die verbond. Allereers het ons 'n negatiewe rol deurdat ons sonde telkens die realisering van God se doel dwarsboom (Adam, uittog, ballingskap, ensovoorts). God se reaksie op ons sonde toon egter telkens 'n verrassende verryking van sy doel en nuwe gestaltes wat sy doel aanneem. Die verryking sien ons byvoorbeeld in die 'nuwe uittog', die terugtog uit die ballingskap wat groter en triomfanteliker voorgestel word as die uittog uit Egipte; die nuwe Jerusalem wat soveel heerliker is as die ou Jerusalem; Jesus as die nuwe koning Dawid; die nuwe aarde, ensovoorts. Dat God ook telkens nuwe dinge doen, nuwe gestaltes van sy doel realiseer, kan ons sien in die nuwe gestalte van Israel, (die Kerk).

Op 'n merkwaardige wyse word die vervulling van die verrykte doel van God saamgetrek in Jesus Christus in wie God se beloftes in hul omvattende verskeidenheid vervul word. Juis in die gestruktureerde wyse waarop God in Jesus-deur-die-Gees sy doel realiseer, kom naas die negatiewe rol van die mens ook die mens se positiewe betekenis na vore. Immers Jesus is dié mens, Hy realiseer die verbond namens die mens, en alhoewel Hy dit in een sin sonder ons realiseer (vir ons), realiseer Hy dit juis ook in ons en met ons (en dus nie sonder ons nie). Vergelyk my Jesus die Laaste (1985).

Hierdie besondere vorm van verbondsteologie probeer dus reg doen 
aan die sterk nadruk op doel en toekoms in heelwat van die Bybelse tradisies, en probeer getrou wees aan die merkwaardige rol van Jesus Christus as die omvattende vervulling van die beloftes van God.

Die feit dat telkens van die verbond as God se skeppingsdoel gepraat word, beklemtoon die omvattende, kosmiese dimensies van God se omgang met sy skepping. In sy skeppingswerk, in sy omgang met Israel en in sy realisering van die verbond in Jesus Christus deur die Heilige Gees, spreek hierdie kosmiese wydheid konsekwent mee.

So 'n alternatiewe vorm van verbondsteologie moet egter nie gesien word as ' $n$ eksklusiewe benadering nie, maar juis in die gees van hierdie bydrae as ' $n$ poging tot vernuwing en verryking van ons insig in die ryke verskeidenheid van die Bybelse boodskap. Teoloë sal groter waarde hê vir die kerk van Christus as hulle meer ekumenies, inklussief en waarderend werk, en almal saam die gelowiges probeer help om hul gesamentlike geloof te verstaan.

Die ruimhartige wyse waarop Ben Engelbrecht my sedert my jong dae aanvaar en bemoedig het, alhoewel ek nie aan die Nederduitsch Hervormde Kerk behoort nie, het bygedra tot hierdie inklusiewe, ekumeniese benadering. 